مقاله يخوهشى

مجله دانشعاه علوم :ز شككى رفسنجان

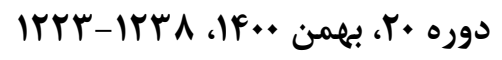

ارزيابى برنامه ادغام دروس ياتولوزى اختصاصى و فارماكولوزى از ديد داه داه دانشجويان

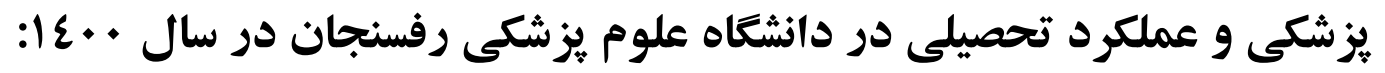
يك مطالعه توصيفى دواه عوم

وحيد ميرزايى '، رضا صابرى، عفت شهر آبادى"

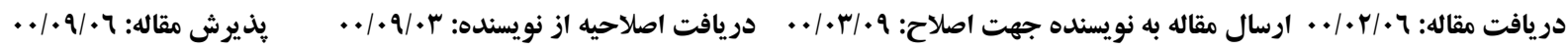

زمينه و هدف: اثربخشى استراتزى ادغام در دروس يزشكى و عملكرد تحصيلى داراى اهميت ويزهاى است. لذا اين مطالعه با هدف

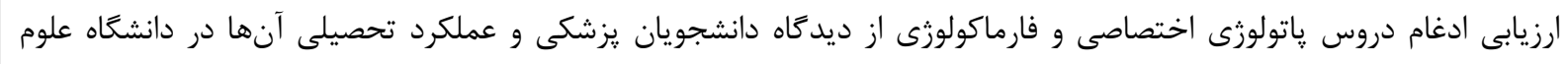
يزشكى رفسنجان انجام شد.

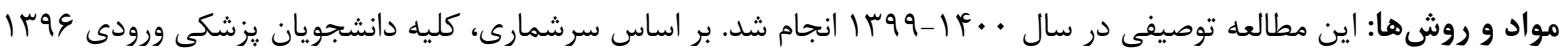

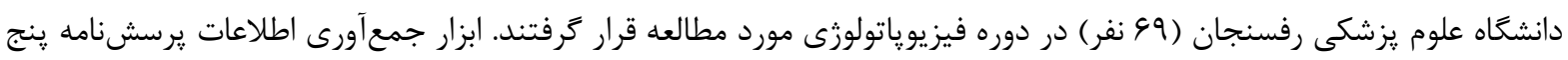

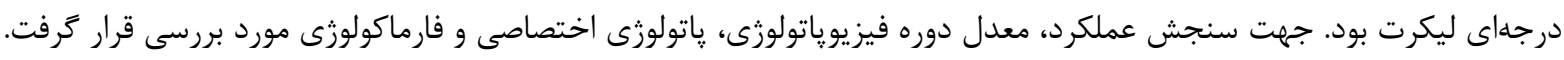

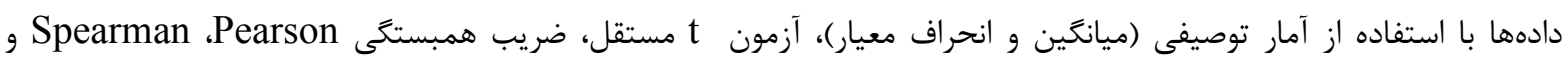
ركرسيون خطى جندَّانه تجزيه و تحليل شد.

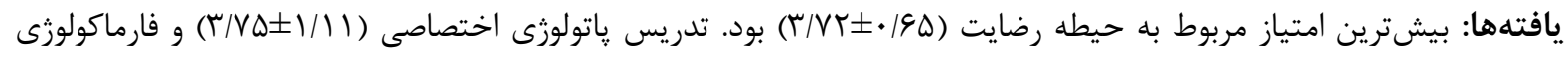

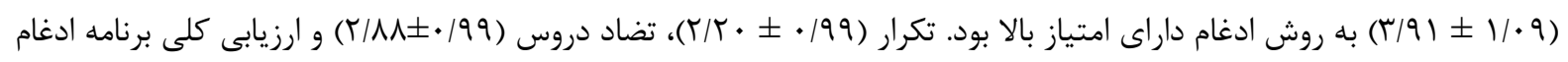

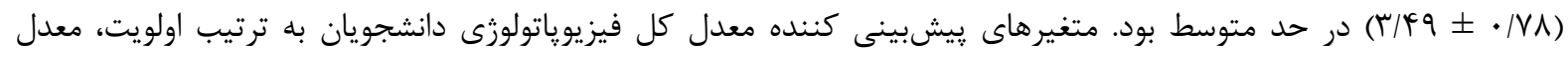

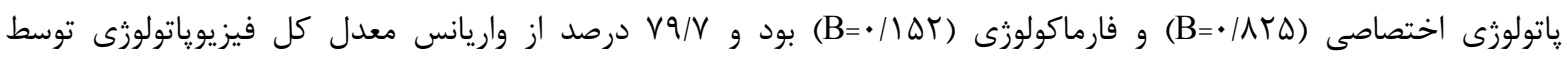

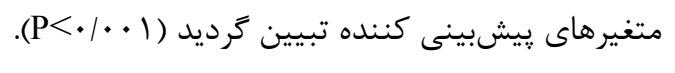

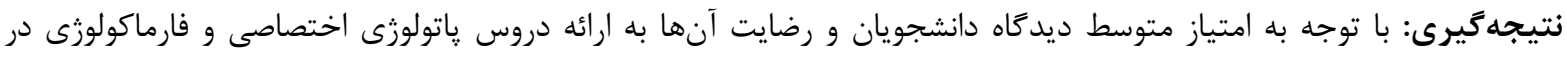

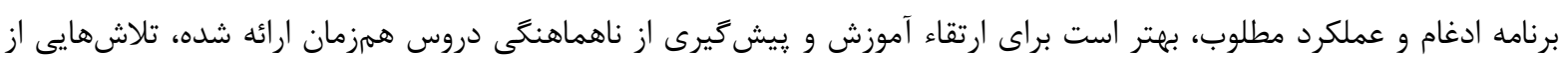
طرف برنامهريزان درسى جهت بهتر اجرا شدن انجام تردد. وازههاى كليدى: استراتزى ادغام، ياتولوزى اختصاصى، فارماكولوزى، دوره فيزيوياتولوزى، عملكرد تحصيلى، رفسنجان

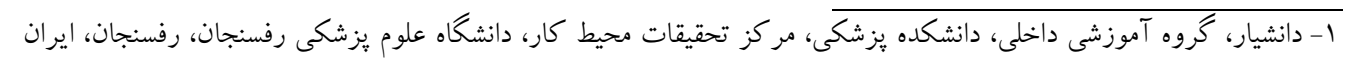

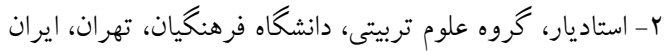

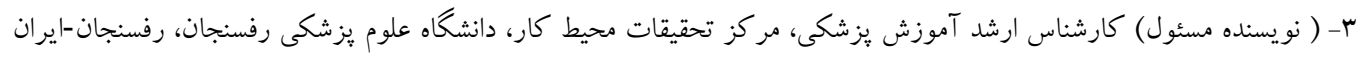

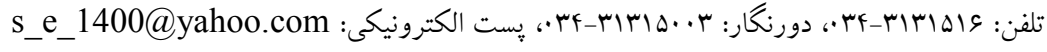


منظم و ساختارمند منظمى براى ارتباط مفاهيم بيمارىهاى مختلف وجود ندارد. درك يا توسعه ارتباط بين مباحث تدريس شده در رشتههاى مختلف به دانشجويان

$$
\text { واگذار مىشود [^-9]. }
$$

در كشور ايران تا جندين سال بيش، رشته يزشكى، برنامه درسى خود را با دوره علوم پايه آغاز، و بعد از امتحان جامع علوم پايه، دوره فيزيوپاتولوزى و دوره بالينى كه با تشخيص، درمان و مراقبت از بيماران است، ادامه مىيافت. دروس به صورت رشته محور و مستقل از هم تدريس مى جامعى نسبت به ساختار و عملكرد بدن انسان و ارتباط بين آنها كسب نمىنمود [1|-•|1]. در روش سنتى، برنامه درسى دانشجويان بزشكى در دوره فيزيوياتولوزى به اين صورت بود كه دانشجويان واحد پِاتولوزى اختصاصى 1 و r و فارماكولوزى ا و r را جداعانه به صورت مجزا از هم فرا مى گرفتند [1/]]. ياتولوزى شامل فيزيوياتولوزى ريه، كليه، گَوارش، قلب، غدد، خون، روماتولوزى، و پاتولوزى اختصاصى نظرى، و عملى جمعاً به تعداد •r واحد و فارماكولوزى نيز به صورت عمومى و اختصاصى، به تفكيك هر كدام Y واحد در دوره يكساله (دو ترم تحصيلى) تدريس مى بايستى خود مطالب را به هم ربط مى دادند تا متوجه شوند كه با توجه به نحوه شناخت بيمارى، تجويز صحيح جه مىباشد. لذا روش ادغام جايگزين روش سنتى گرديده
ادغام يا تلفيق (Integration)، تركيب واحدهاى جدا از هم و تشكيل يك سيستم يكيارجه مىباشد [1] و به عنوان يك استراترى براى انسجام، ارتباط و جذاب بودن تجارب آموزشى در نظر گرفته مىشود. به عبارتى اتصال موضوعهاى مختلف و يادگيرى در سطوح بالاتر را تسهيل

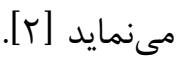
استراتزى ادغام توسط Harden براى آموزش يزشكى معرفى گرديد. وى ادغام را يكى از مهممترين استراتزىهاى برنامه آموزشى رشته يزشكى مىداند و $\mid ل$ يله را براى آن معرفى نمود [ץ]. Fogarty نيز از صاحبنظران برنامه ادغام، ·ل مدل براى طراحى برنامه ارائه نمود كه به فراگيران كمى مى كند هنگام يادگيرى ارتباطات ارزشمندى برقرار كنند [ه-f]. لذا، بنا به شرايط حاكم بر هر برنامه آموزشى مىتوان انواعى از استراتثىهاى ادغام را به كار برد [ع]، از قبيل ارتباط موضوعات كه خود شامل ادغام افقى و عمودى است [ع]. در ادغام افقى، مطالب حول يك محور باز آرايى مى گردند. اين محور مطالب در علوم پايه اركانهاى بدن و در دوره فيزيوياتولوزى بيمارىها مىباشند [V]] در ادغام عمودى، قسمتى از مطالب علوم ֶايه به بالين و يا برعكس منتقل مىشود [ع-V]. مطالعات نشان مىدهد كه سيستم فعلى آموزش يزشكى، يراكنده است. موضوعات به صورت مجزا با تكرارهاى غير ضرورى آموزش داده مىشوند. هيج تلاش 
ادغام به عنوان رويكرد مناسبى در جهت ارتقاء و بهبود روند آموزش يزشكى عمومى بيان نمودهاند [.r. V] بعضى از مطالعات ادغام دروس علوم پايه و بالينى را بررسى نموده و نتايج مطالعه آنها نشان دهنده افزايش توانايى دانشجويان در اين طرح بوده است [1/T]. Alami و همكارش نيز بيان نمودند كه روش ادغام در ارائه برنامههاى آموزشى در دوره فيزيوياتولوزى، عملكرد دانشجويان يزشكى را در آزمون جامع بيش كارورزى به ويزه در درس

آسيبشناسى ارتقاء داده است [ها ].

به نظر مىرسد با توجه به مطالب فوق، بررسى ديدگاه دانشجويان در اين زمينه از اهميت ويزهاى برخوردار است. بنابراين، سؤال اين است علىرغم اين كه تغيير از روش سنتى به روش ادغام در دوره فيزيوياتولوزى جهت دروس ياتولوزى اختصاصى و فارماكولوزى انجام گرفته است، باعث افزايش تمركز روى موضوع و بهبود عملكرد ياد گيرنده در دانشگاه گرديده است؟ به عبارتى با توجه به حجم بالا و گستردگى مطالب در خصوص بيمارىها و فارماكولوزى، روش ادغام توانسته است نحوه صحيح شناخت بيمارىها و تجويز داروها را براى دانشجويان يزشكى تسهيل نمايد؟ Mehrmohammadi و همكارانش در ترجمه مطلبى از Decker Walker بيان نمودند كه Fاهى اوقات يك نظريه خوب با اجرايى نامناسب، به نتايج نادرستى منتهى مى گردد. اين ايرادى بر نظريه وارد نمىكند، بلكه مهرم اين است كه نسبت به كاربرد دقيق و
است. در روش ادغام، همزمان با مباحث فيزيوياتولوزى سيستم مربوطه (قلب، ريه، كليه، توارش و غيره) فارماكولوزى آن سيستم (قلب، ريه، كليه، گوارش و غيره) نيز آموزش داده مىشود. اولين دانشخاههايى كه در ايران استراتزى مذكور را در خصوص برنامه درسى دانشجويان يزشكى به كار بردند، دانشخاه علوم يزشكى شهيد بهشتى بود و دانشخاههاى ديخر به مرور جهت تسهيل يادگيرى و ارتباط موضوعات علوم پايه با بالينى شروع به استفاده

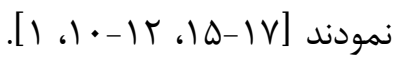
دانشگاه علوم يزشكى رفسنجان نيز جهت دانشجويان يزشكى ورودى سال عهبا و بعد از آن، دوره فيزيوياتولوزى را با استراتزى مذكور به اجرا كذراده است. مطالعاتى در اين زمينه انجام شده است به طورى كه Husian و همكارانش بيان نمودند كه ادغام، يكى از تغييرات عمده در برنامه درسى مبتنى بر صلاحيت در برنامه رشته يزشكى در كشور هند مىباشد [11]. Chhabra دستيارن بىهوشى معتقدند كه كلاسهاى ادغام در عمل بالينى آنها بسيار مفيد است. آنها بيان نمودند كه كلاسهاى ادغام با آناتومى به خوبى درك مىشود و براى آموزش بهتر و مراقبت بهتر از بيمار برنامه درسى ادغام عمودى نيز در دورههاى تخصص يزشكى بايد به كار رود [19]. همرجنين، مطالعاتى بهبود نسبى عملكرد تحصيلى دانشجويان و رضايتمندى آنها بهدنبال اجراى روش 
ع ا I ارزيابى برنامه ادغام دروس ياتولوزى اختصاصى و فارماكولوزى

را براى اولين مرتبه به صورت ادغام گذراندهاند، مورد مطالعه قرار ترفتند. از اين تعداد أ نفر از دانشجويان كه دوره فيزيوياتولوزى مهمان دانشگاههاى علوم يزشكى ساير نقاط كشور بوده و يك نفر نيز كه به دليل عدم نمره قبولى در امتحان جامع علوم پايه نتوانست وارد دوره مذكور شود، از مطالعه خارج شدند. در نهايت براى ادغام دوره فيزيوياتولوزى 94 نفر از دانشجويان مورد بررسى قرار كرفتند. لازم به ذكر است تعداد ץ نفر از دانشجويان ورودى سال هوبا دانشعاه كه با ورودىهاى سال عهץ" دوره فيزيوياتولوزى را شروع كردند، جزء جامعه آمارى

$$
\text { محسوب كرديدند. }
$$

جهت جمع آورى دادهها از يرسشنامه Zare-Khormizi و همكارانش استفاده شد [1/1]. ضريب آلفاى كرونباخ يرسشنامه مذكور VYT/ بود. ولى از آنجايى كه برخى از سؤالات زرسشنامه ويرايش گرديد، روايى و پرايايى يرسشنامه مذكور بررسى شد. براى محاسبه يايايى، تعداد

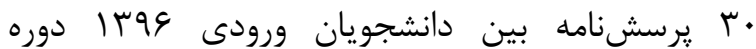
فيزيوياتولوزى كه جزء نمونه اصلى مطالعه بودند، توزيع و ياسخها وارد نرمافزار گرديد و از آلفاى كرونباخ استفاده گرديد كه N\&V| • به دست آمد. روايى محتوايى و صورى با استفاده از نظرات ץ نفر از متخصصين فيزيوياتولوزى و آموزش يزشكى انجام گرديد. بدين منظور براى بررسى روايى محتوايى، سؤالهاى يرسشنامه در اختيار متخصصان مذكور كذاشته شد. از آنها درخواست گرديد
انتقادى در موقعيتهاى مربوطه، توجه بيشترى به خرج داد [بr]. لذا، با توجه به اين كه در اين خصوص معدود تحقيقاتى در دانشگاههاى علوم يزشكى كشور انجام كرديده است [ع|-ها، ז1] در دروس مختلف، بستكى به عوامل متعددى از جمله نحوه تدريس اساتيد، امكانات دانشكاهها و غيره دارد [Y I] و هر دانشخاهى شرايط مخصوص به خود را دارد و هم جنين از آنجايى كه در دانشگاه علوم يزشكى رفسنجان جنين تحقيقى در خصوص ارزيابى برنامه ادغام در دروس پاتولوزى اختصاصى و فارماكولوزى از ديدگاه دانشجويان يزشكى انجام نكرديده و مدت زمان كوتاهى است كه اين برنامه در دانشخاه مذكور به اجرا كذاشته شده است، به نظر مىرسد ضرورت بهدست آوردن ديدگاه دانشجويان هر دانشگاه بعد از يِاده نمودن آن استراتزى لازم مىباشد. لذا تحقيق حاضر با هدف ارزيابى ادغام دروس پاتولوزى اختصاصى و فارماكولوزى از ديدگاه دانشجويان :زشكى دانشعاه علوم يزشكى رفسنجان و عملكرد آنها در سال

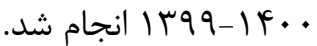

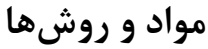

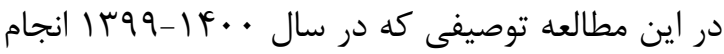
شد، بر اساس سرشمارى، كليه دانشجويان :زشكى ورودى و 119 دانشعاه علوم يزشكى رفسنجان (VY) نفر) كه دروس پاتولوزى اختصاصى و فارماكولوزى (قلب، تنفس، كليه، تناسلى، اعصاب، خون، گوارش، كبد، يوست و غدد) 
(يك امتياز)، تنظيم گرديده است. حداكثر ميانگين امتياز به تفكيك حيطهها، له امتياز و حداقل يك امتياز بود. در حيطه آموزش، در خصوص سؤالات "تكرار مباحث دروس در روش ادغام نسبت به روش معمول (سنتى)" و "تضاد در دروس ادغام نسبت به روش معمول (سنتى)"، امتيازدهى به صورت معكوس است. به اين صورت كه خيلى زياد ( امتياز)، زياد (r امتياز)، متوسط (ب امتياز)، كم (4 امتياز) و هيج (له امتياز) تعيين شد. حداكثر نمره اكتسابى براى هر مقياس، ه و حداقل يك امتياز بود. و براى كل يرسشنامه با استفاده از ميانگين دادها، حداكثر نمره اكتسابى ه و حداقل نمره ا در نظر گرفته شد. با توجه به اندازهزيرى يرسشنامه از نوع ليكرت، محدوده امتياز صفر تا ه/ إ وضعيت ديدكاه دانشجويان ضعيف،

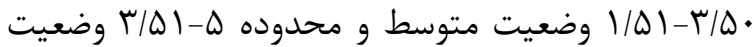
عالى محسوب گرديد [سץ]. كسب امتياز بالا در هر حيطه و در كل يرسشنامه، به ترتيب نشاندهنده ديدگاه مثبت دانشجويان نسبت به آن حيطه و اجراى موفق استراتثى

$$
\text { مذكور در ارزيابى كلى حيطهها است. }
$$

اطلاعات مربوط به عملكرد دانشجويان با استفاده از معدل دوره فيزيوياتولوزى، فارماكولوزى و پِاتولوزى اختصاصى از آموزش دانشكده اخذ ترديد. به منظور رعايت ملاحظات اخلاقى در اين يروهش، يس از تصويب مطالعه در ميته اخلاق (IR.RUMS.REC.1400.005)
كه مشخص كنند آيا سؤالات آزمون، صفت مورد نظر را اندازمخيرى مى كند و آيا سؤالها كل محتواى آزمون را در بر مى گيرد. ضمناً رعايت دستور زبان، استفاده از كلمات مناسب، اهميت سؤالها، قرارگيرى سؤالها در جاى مناسب و زمان تكميل ابزار را نيز مد نظر قرار دهند. پس از جمعآورى نظرات، تغييرات لازم در ابزار مورد توجه قرار كرفت و بعد از توافق نهايى، روايى محتوايى تأييد گرديد. در تعيين روايى صورى، براى يافتن سطح دشوارى، ميزان عدم تناسب، ابهام عبارات و يا وجود نارسايى در معناى كلمات، متخصصين مذكور يرسشنامه را بررسى و نظرات آنان با تغييرات جزيى در يرسشنامه اعمال گرديد. اين تغييرات از قبيل: سؤالهاى 9، 11 و זا، به جاى كلمه "كورس"، "روش معمول (سنتى)" و در سوال IV "كلاسهاى عملى" اضافه شد. در مجموع با دادهاى مطالعه حاضر، روايى و پايايى :رسشنامه مورد سنجش

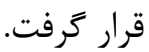
ابزار مورد استفاده شامل دو قسمت است. قسمت اول، مشخصات دموكرافيك دانشجويان شامل: سن، جنسيت، سال ورودى. قسمت دوم سؤالات يرسشنامه كه FF سؤال

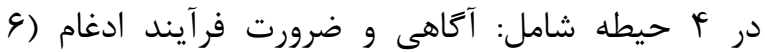
سؤال)، آموزش (9 سؤال)، وجود امكانات (r سؤال) و رضايت از برنامه تلفيق (V سؤال) است. سؤالات بر اساس مقياس زنج درجهاى ليكرت شامل خيلى زياد (ه امتياز)، زياد (ץ امتياز)، متوسط (ץ امتياز)، كم (ץ امتياز) و هيج 
1 I T ارزيابى برنامه ادغام دروس ياتولوزى اختصاصى و فارماكولوزى

يرسشنامه را تكميل نمودند. در اين مطالعه تعداد زنان • نفر ( $F$ ( بود. دامنه سنى افراد در محدوده FY

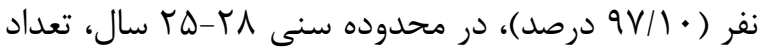
r نفر (/A9 درصد) و بيشترين فراوانى مربوط به سن

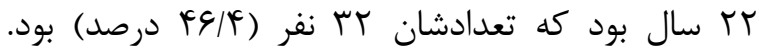
فراوانى دانشجويان ورودى سال هوسا به تعداد ץ نفر

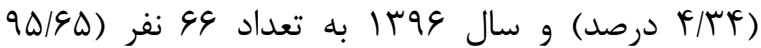
درصد) و ميانگين و انحراف معيار معدل دانشجويان به

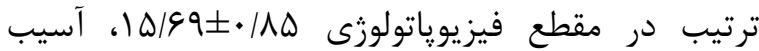

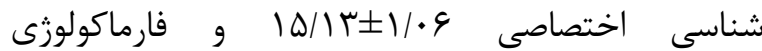

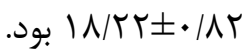

در جدول ا، ديدگاه دانشجويان نسبت به ادغام دروس ״ֶاتولوزى و فارماكولوزى گزارش شده است. از ميان حيطهها بيشترين امتياز مربوط به رضايت از سيستم

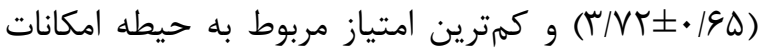

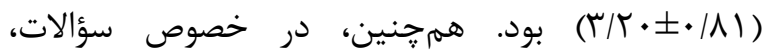
موافقت با تدريس دروس به صورت سنتى از كمترين امتياز (T//NF I/NF) و ضرورت ارائه فارماكولوزى در

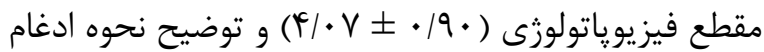
دروس در ابتداى دوره فيزيوياتولوزى (^9/• بيشترين امتيازات را نشان مىدهند.
وضعيت بحرانى ويروس كرونا، به صورت الكترونيك طراحى گرديد و به دانشجويانى كه معيار ورود را دارا بودند (دانشجويانى يزشكى ورودى سال \&9щ1 دانشگاه علوم يزشكى رفسنجان كه دوره فيزيوياتولوزى را به صورت ادغام مى گذراندند) ارسال گرديد. يُ از گردآورى و كدگذارى اطلاعات، جهت تجزيه و تحليل دادها از SPSS نسخه 19 استفاده شد. نتايج به صورت ميانغين، انحراف معيار، آزمون t مستقل، ضريب همبستخى Pearson و Spearman و ركرسيون خطى جندكانه مرحله به مرحله (Stepwise) محاسبه و تزارش كرديد. يِش فرضهاى رگرسيون از قبيل كمى بودن متغير وابسته (معدل كل فيزيوياتولوزى)، نرمال بودن توزيع متغير وابسته (توزيع نرمال هيستوگرام براى معدل كل فيزيوياتولوزى)، خطاها داراى توزيع نرمال با ميانخين صفر و يراكندگى دادهها حول خط رگرسيون ثابت و استقلال خطاها با استفاده از آماره Durbin Watson برابر

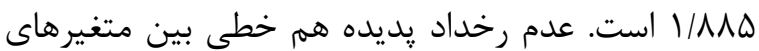
״يش بين وجود داشت (جدول r). سطح معنى دارى ه •/

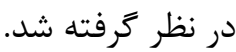
نتايج

نتايح نشان داد كه تمامى 99 نفر دانشجويان كه از طريق استراتزى ادغام مقطع تحصيلى فيزيوياتولوزى را در دانشخاه علوم يزشكى رفسنجان پشت سر گذاشتهاند، 


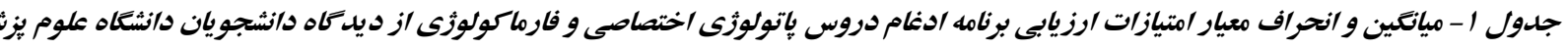

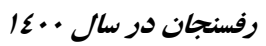

\begin{tabular}{|c|c|c|c|c|}
\hline ميانكين و انحراف & ميانغين و انحراف معيار & 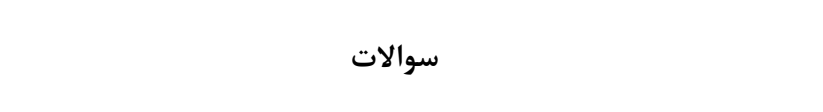 & $\widehat{\hat{s}}$ & 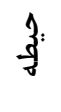 \\
\hline \multirow{6}{*}{$r / 99 \pm \cdot / 9}$. & $r / 19 \pm \cdot / 99$ & آشنايى با اهداف دروس ادغام & 1 & \\
\hline & $\varphi / \cdot r \pm \cdot / \wedge q$ & توضيح نحوه ادغام دروس در ابتداى دوره فيزيوياتولورى & r & q \\
\hline & $r / q \uparrow \pm \cdot / \Lambda q$ & تسهيل يادَيرى در ادغام دروس دوره فيزيوياتولوزى & r & $\hat{2}^{2}$ \\
\hline & $r / \wedge \gamma \pm \cdot / 9 \Delta$ & درك عميقتر مطالب و ارتقاء دانش & r & $j^{\circ}$ \\
\hline & $r / 9 r \pm \cdot / 91$ & تأثير بر انگَيزه دانشجو در مطالعه دروس ادغام & $\Delta$ & $\frac{3}{a}$ \\
\hline & $r / \mu r \pm 1 / \cdot r$ & تأثير برحضور دانشجو در دروس ادغام & \& & \\
\hline \multirow{9}{*}{$r / r q \pm 1 / \cdot \Delta$} & $r / 19 \pm \cdot / 9 F$ & شيوه ارائه دروس به روش ادغام & $\checkmark$ & \\
\hline & $r / \Lambda V \pm \cdot / \Lambda \gamma$ & ميزان تأثير به خاطر سيارى مطالب در ادغام & $\wedge$ & \\
\hline & $r / r \cdot \pm \cdot / 99$ & تكرار مباحث دروس در روش ادغام نسبت به روش معمول (سنتى) & 9 & \\
\hline & $r / 4 r \pm 1 / \cdot 9$ & 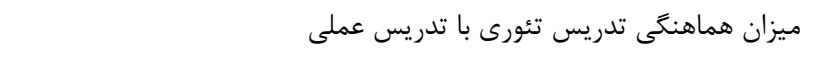 & 1. & \\
\hline & $r / \Lambda \Lambda \pm \cdot / 99$ & تضاد در دروس ادغام نسبت به روش معمول (سنتى) & 11 & $\hat{\jmath}$ \\
\hline & $r / g r \pm \cdot / \Lambda F$ & تناسب حجم ارائه شده دروس به روش ادغام نسبت به روش معمول (سنتى) & ir & \\
\hline & $r / V \Lambda \pm \cdot / q$. & 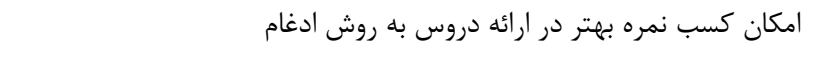 & ir & \\
\hline & $r / 9 r \pm 1 / \cdot r$ & ضرورت تدريس عملى دروس به صورت آموزش الكترونيكى مجازى & If & \\
\hline & $r / 9 \uparrow \pm \cdot / \wedge 9$ & ضرورت تدريس تئورى دروس به صورت آموزش الكترونيكى مجازى & 10 & \\
\hline \multirow{2}{*}{$r / r \cdot \pm \cdot|\Lambda|$} & 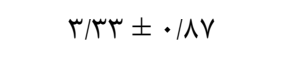 & در دسترس بودن منابع مطالعاتى مناسب & 19 & $\overline{3}$ \\
\hline & $r / \cdot v \pm \cdot / 9 \varphi$ & ارزيابى امكانات آزمايشكاه (كلاسهاى عملى) & iv & \\
\hline \multirow{8}{*}{$r / V T \pm \cdot 190$} & $r / A F \pm 1 / 1 r$ & موافقت با تدريس دروس به شيوه سنتى & 11 & \\
\hline & $r / \Lambda \Lambda \pm \cdot / 99$ & موافقت با تدريس دروس به شيوه ادغام & 19 & . \\
\hline & $r / 91 \pm 1 / \cdot 9$ & موافقت با تدريس فارماكولوزى به شيوه ادغام & r. & 3 \\
\hline & $\varphi / v \pm \cdot / q$ & ضرورت ارائه فارماكولورى در مقطع فيزيوياتولوزى & rI & \\
\hline & $r / V \Delta \pm 1 / 11$ & موافقت با ارائه پاتولوزى اختصاصى به شيوه ادغام & rt & : \\
\hline & $r / \& \Lambda \pm 1 / 11$ & موافقت با ارائه پاتولورى اختصاصى در مقطع فيزيوياتولوزى & r & $\frac{\bar{y}}{\underline{y}}$ \\
\hline & $r / 91 \pm 1 / \cdot r$ & موافقت با ارائه فارماكولوزى عملى به شيوه ادغام & rF & \\
\hline & $r / 91 \pm 1 / \cdot r$ & اجراى شيوه ادغام براى دانشجويان ديكر & ra & \\
\hline$r / \& q \pm \cdot / v \wedge$ & & ميانگَين امتيازات كل حيطهها & & ફ. \\
\hline
\end{tabular}

داشت. اما بر اساس آزمون همبستخى Spearman، بين معدل

كل دوره فيزيوياتولوزى دانشجويان با متغيرهاى سن

$(\mathrm{r}=\cdot / \cdots, \mathrm{P}=1) \quad(\mathrm{r}=-\cdot / \mid 9) \quad \mathrm{P}=\cdot / \mid \wedge \mathrm{V})$

همبستگى معنى دارى مشاهده نشد. همرجنين، ارتباط بين
نتايج نشان داد كه بر اساس آزمون همبستگى Pearson،

بين معدل كل دوره فيزيوياتولوزى دانشجويان با معدل

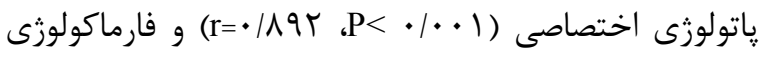
همبستخى مثبت و معنى دارى وجود $)$ 
• ب ا ا ارزيابى برنامه ادغام دروس ياتولوزى اختصاصى و فارماكولوزى

دست آمده، به ازاى هر يك نمره افزايش در معدل پاتولوزى

اختصاصى و فارماكولوزى، به ترتيب معدل فيزيوياتولوزى به

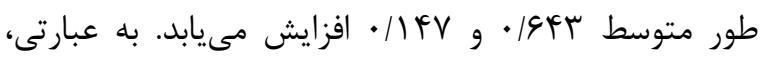
معدل پِاتولوزى اختصاصى با ضريب استاندارد هTA/• بيشترين و معدل فارماكولوزى با ضريب استاندارد هA / • . در مرحله بعدى باعث افزايش معدل كل فيزيوياتولوزى مىشود. متغيرهاى سن و سال ورود به دليل معنادار نبودن، ارتباطى با متغير ملاك (معدل كل فيزيوياتولوزى) نداشتند و در مدل ركرسيونى خطى جند
معدل كل دوره فيزيوياتولوزى و جنسيت دانشجويان بر

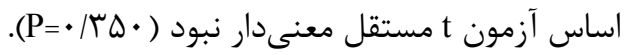
بر طبق جدول ז، پيشبينى معدل كل دوره فيزيوياتولوزى (متغير ملاك) با معدل كل فارماكولوزى، پاتولوزى اختصاصى و متغيرهاى دموكرافيك سن و سال ورود (متغيرهاى پيشبين)، حاكى از آن است كه متغيرهاى ״يشبين مىتوانند تا V9/V درصد از واريانس معدل فيزيوياتولوزى را تبيين كنند. آزمون F، مقدار معنادارى را

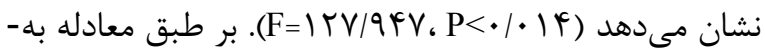
جدول ب - نتايج ركوسيون خطى جندكانه مرحله به مرحله (Stepwise) دو بيشبينى معدل كل دوره فيزيوياتولوزى دانشجويان دانشكاه علوم

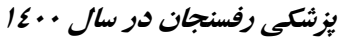

\begin{tabular}{|c|c|c|c|c|c|c|c|}
\hline \multicolumn{2}{|c|}{ Collinearity statistics } & \multirow{2}{*}{ مقدار p } & \multirow{2}{*}{ مقدارt } & \multirow{2}{*}{ ضر استاندارد } & \multirow{2}{*}{ 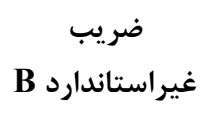 } & \multirow{2}{*}{ ضعريب } & \multirow{2}{*}{ متغير بيشبين } \\
\hline Tollerence & VIF & & & & & & \\
\hline - IASF & $1 / 1 \Delta \Lambda$ & $<\cdot \mid \cdot \cdot 1$ & $|r / V A|$ & - /ATA &. $\mid 944$ & \multirow{2}{*}{ •/vq } & معدل پِاتولوزى اختصاصى \\
\hline - INAF & $1 / 1 \Delta \Lambda$ & .1 .14 & T/QTA & . /lQT &.$/ l \mathrm{kV}$ & & معدل فارماكولوزى \\
\hline
\end{tabular}

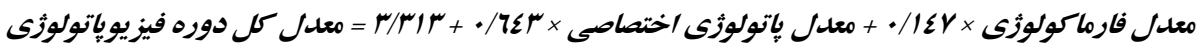

شيوه ادغام" و "اجراى شيوه ادغام براى دانشجويان ديخر" بحث

امتيازات از وضعيت عالى برخوردار هستند. مطالعه Nasiri و

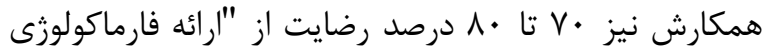
در قالب طرح ادغام"؛ "ارائه فارماكولوزى در مقطع فيزيوياتولوزى" و "ادامه اجراى طرح ادغام براى ساير دانشجويان" را بيان نمودند كه همسو با مطالعه اخير است Rehman .[V] تلفيقى را در VA درصد دانشجويان نشان دادند [Yr]. در مطالعهاى كه توسط Sherer و همكارانش با عنوان "تأثير مثبت تلفيق آموزش بافت شناسى و فيزيولوزى در دانشكده
يروهش حاضر با هدف ارزيابى برنامه ادغام دروس ״اتولوزى اختصاصى و فارماكولوزى از ديدكاه دانشجويان يزشكى دانشگاه علوم يزشكى رفسنجان و عملكرد تحصيلى آنها انجام شد. نتايج مطالعه، بالا بودن امتياز در حيطه رضايت از سيستم ادغام توسط دانشجويان را نشان مىدهد. به طورى كه در گويههاى "موافقت با تدريس دروس به صورت ادغام"، "موافقت با تدريس فارماكولوزى به شيوه ادغام"، "ضرورت ارائه فارماكولوزى در مقطع فيزيوياتولوزى"، "موافقت با ارائه ياتولوزى اختصاصى به 
[عץ]. Eisenbarth و همكارانش در مطالعهاى به روش تركيبى كه ارزش و نقش دورههاى علوم ادغام شده در برنامه ادغام به عبارتى برنامه اصلاحات دروس يزشكى را مورد جستحو قرار دادند، بيان نمودند كه استراتثى تلفيق، انخيزه و درك مفهومى دانشجويان را افزايش مىدهد. اما آنها بيان نمودند علىرغم رضايت دانشجويان از برنامه تلفيق، بعضى از دورههاى درسى هنوز نياز به بهينهسازى دارند [rV]. محققين مطالعهاى كه عدم آكاهى را در خصوص ادغام نشان دهد، را ييدا ننمودند. لذا به نظر مىرسد دانشعاههايى كه اقدام به اجرايى نمودن برنامه مذكور مى نمايند، زمينه آكاهى دانشجويان را نيز فراهم مى آورند. حيطه آموزش در مطالعه اخير نيز از امتيازات متوسط برخوردار بود. در اين مطالعه گويههاى، ميزان تأثير به خاطر سيارى مطالب در ادغام، تناسب حجم ارائه شده دروس به روش ادغام نسبت به روش سنتى، امكان كسب نمره بهتر در ارائه دروس به روش ادغام، ضرورت تدريس عملى دروس به صورت آموزش الكترونيكى مجازى و ضرورت تدريس تئورى دروس به صورت آموزش الكترونيكى مجازى با توجه به نقطه برش از وضعيت عالى برخوردار بودند. Eisenbarth و همكاران نيز گزارش نمودند كه برنامه تلفيقى، تجربه ذهنى دانشجويان در به خاطر سيارى دانش را تسهيل مىكند [rV] [ب] در مطالعه حاضر تكرار دروس و تضاد در ادغام نسبت به روش سنتى با توجه به نقطه برش وضعيت متوسط را نشان داد. يافتههاى مطالعه Ahmadipour و همكارش در كرمان در خصوص ادغام افقى در دروس علوم پِايه، نشان داد
يزشكى در جين" انجام شده است، بيان شد كه دانشجويان دوره برنامه درسى ادغام شده در بيشتر موارد نسبت به دوره خود و روشهاى جديد آموزشى راضى بودند [ها]]. به نظر مىرسد كه تغيير استراتزى از سنتى به استراتزى ادغام ضرورى مىباشد. مهمم اين است كه مؤسسات تا خه اندازه مىتوانند پِلهاى استراتزى Harden [r] و يا برنامه تلفيقى [ Fogarty همكارانش كه در دانشكاه علوم يزشكى يزد در اين زمينه بررسى شد، نتايج رضايت از سيستم در حد متوسط گزارش كرديد كه با مطالعه حاضر همخوانى ندارد [1/] احتمالاً مواردى مانند نحوه اجراى آموزش، سازماندهى محتوا، و تجهيزات مىتواند در اين خصوص تأثيركذار باشد و باعث

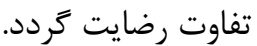
نتايج مطالعه اخير، حيطه آكاهى و ضرورت اجراى فرآيند

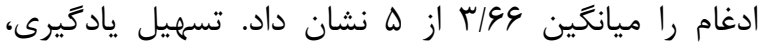
درك عميقتر و انخيزه از مواردى بودند كه دانشجويان امتياز بالايى را به آنها اختصاص دادند. در اين خصوص Vashe و همكارانش در يزوهشى با عنوان استفاده از يك رويكرد تدريس تلفيقى براى تسهيل پيشرفت نتايج يادگيرى دانشجو در يك برنامه درسى پيش بالينى يزشكى در هند، بيان نمودند كه اكثريت دانشجويان به همه سؤالات ياسخ مثبت دادند به طورى كه ه/ه/ه در صد دانشجويان افزايش انخيزه براى يادگيرى، و 9/9 درصد بهبود فهم موضوعات درسى، 91/T درصد كمك در كسب دانش عميق موضوع را از موارد مثبت رويكرد تدريس تلفيقى در دانشگاه خود دانستند 
TrF ا ارزيابى برنامه ادغام دروس ياتولوزى اختصاصى و فارماكولوزى

مىباشد. آنها بيان نمودند كه در تحقيق انجام شده توسط آنها، 9/V9 درصد دانشجويان، برنامه درسى ادغام را كسب تجربdهاى بهتر يادگيرى مىدانند و 1/K درصد معتقد به درك و به كارگيرى بهتر علوم دارويى در عمل در مقايسه با دورههاى سنتى بودند [^ج]. به نظر مىرسد با تحقيقات گستردهر به دنبال حجم نمونه بيشتر (بهدليل پشت سركذاشتن دوره تحصيلى به روش ادغام در ورودىهاى بعد

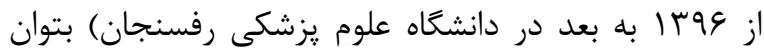
نقاط ضعف و قوت اجراى استراتزى مربوطه را بهدست آورد و در جهت ارتقاء استراتثى مربوطه گامهاى مؤثرترى برداشت. با توجه به يافتههاى مطالعه، معدل دوره پِاتولوزى اختصاصى و فارماكولوزى يِيشبينى كننده معدل دوره فيزيوياتولوزى است. در اين زمينه مطالعات همسو وجود دارد. Allami و همكارش زَزارش نمودند كه ادغام آسيبشناسى با ساير دروس فيزيوياتولوزى باعث بهبود وضعيت نمرات دانشجويان در آزمون پِيش كارورزى كرديده و كسب نمره بالاتر و درك بهتر موضوعات مرتبط را فراهم نموده است [ها]. به نظر مىرسد ادغام مىتواند زمينه عملكرد بهتر را در دانشجويان بهدليل ارتباط موضوعات با هم فراهم نمايد. يزوهش گران مطالعه حاضر نتوانستند، مطالعاتى در خصوص ضعف عملكرد با روش ادغام، بيدا نمايند. لذا بايستى با مطالعات گستردهتر در سالهاى متمادى بعدى و مقايسه با يكديخر در خصوص تعميم نتايج تصميمىيرى نمود.
كه QF/9 درصد دانشجويان كاهش محتواى تكرارى را بيان نمودند [ [1]. اما Nasiri و همكارش بيان نمودند علىرغم استراترى ادغام، تكرار بعضى از مباحث فارماكولوزِى در فيزيوياتولوزى اتفاق مىافتاد و اين مبحث مورد اشكال برنامه ادغام آنها واقع كرديده بود [V]]. بايستى اذعان نمود از آنجايى كه يكى از مهمترين عوامل دستيابى به استراتزى ادغام، حيطه آموزش مىباشد بايستى برنامهريزان درسى، به همراه تصميهَيران آموزشى از جنبههاى مختلف، اين حيطه را در صدر اولويتهاى آموزشى قرار دهند [V]، تا بتوانند ايرادات استراتزى مربوط را شناسايى و برطرف نمايند. در مطالعه حاضر منابع مطالعاتى مورد استفاده و امكانات آزمايشگاهى كه براى كلاسهاى عملى دانشجويان مورد استفاده قرار مى گيرد از امتياز متوسطى برخوردار بود كه همسو با مطالعات ديگر بود [1/I]، به طورى كه Miles و همكارانش محيط آموزشى را بر رضايت از برنامه درسى و موفقيت تحصيلى مؤثر مىدانند [^^]. به نظر مىرسد بايستى جهت حصول استراتزى تلفيق، امكانات لازم نيز به اندازه كافى در دسترس افراد قرارگيرد تا بتوان شاهد موفقيت بيشترى در خصوص اين روش بود. نتايج مطالعه حاضر در ارزيابى كل حيطهها (آكاهى، آموزش، امكانات و رضايت) از ديدگاه دانشجويان وضعيت

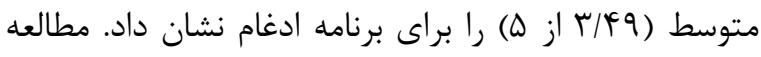
Zare-Khormizi D) را نشان داد كه همسو مطالعه حاضر مىباشد [1 II]. اما مطالعه Alrasheedy با بررسى مطالعه حاضر ناهمسو 
بيشتر انجام شود. پيشنههاد مى ديدگاه دانشجويان ورودىهاى مختلف در خصوص استراتزى ادغام مطالعات بيشترى انجام گردد. بنا به پيشنههاد و همكارانش جهت تعميم مطالب براى رياده نمودن استراتزى ادغام، ارزيابى ادغام برنامه درسى شامل جمعآورى اطلاعات در مورد مسائل و مزاياى اين استراترى با استفاده از ابزارها و روشهاى مختلف باشد. اين روشها ممكن است برخى از بينشهاى معتبر در مورد اجراى تلفيق برنامه درسى را ارائه دهد كه مىتواند منجر به تصميمى كافى در مورد تنظيم آن شود [اس]. تيم يزوهشگر نيز با نظر فوق موافق مىباشد تا بتوانند تعميم نتايج را با دقت بيشترى انجام دهند.

\section{نتيجه گَيرى}

نتايج نشان داد كه ارزيابى دروس پاتولوزى اختصاصى و فارماكولوزى از ديدگاه دانشجويان در حد متوسط و رضايت آنها به ارائه دروس ياتولوزى اختصاصى و فارماكولوزى در برنامه ادغام و عملكرد مطلوب از دستاوردهاى مورد بررسى است. بهتر است حيطه آموزش كه يكى از مهمترين عوامل دستيابى به استراتزى ادغام است در صدر اولويتهاى آموزشى قرار گيرد. براى يیشگيرى از ناهماهنگى دروس همزمان ارائه شده، تلاشهايى از طرف برنامهريزان درسى و دست اندركاران حوزه آموزش جهت بهتر اجرا شدن انجام كردد، تا از تكرار و تضاد دروس ارائه شده تا حد امكان جلوگيرى به عمل آمده و ادامه ادغام در برنامههاى درسى
همانطور كه ديدكاه دانشجويان در اين مطالعه نشان مى دهد ادامه ادغام براى ساير دانشجويان مناسب است (ميانكين | Jalilian و همكاران نيز در مطالعهاى (ه) همسو با مطالعه اخير، ادامه ادغام جهت دورههاى ديگر را مناسب دانستهاند [91]]. همرجنين، Bandiera و همكاران در مطالعهاى تمايل برنامههاى درسى جديد بر تأكيد ادغام جهت توسعه شايستگىهاى و توانمندىهاى متنوعتر يزشكان را بيان نمودند. [•r]]. تيم يزوهش گر، مطالعهاى در خصوص عدم ادامه روش ادغام ريدا ننمودند. به نظر مىرسد حال كه مطالعات ادامه روش را ي يشنهاد نمودند بايستى به طور منظم، ارزيابى از برنامه هر از جند گاهى توسط دستاندكاران انجام يذيرد تا بتوانند نقاط قوت و ضعفهاى مربوطه را ييدا و در جهت ارتقاء آنها تلاش نمايند. از محدوديتهاى مطالعه اخير، بهدليل وضعيت بحران كوويد-19 و ادامه آموزش در دانشخاهها، برگزارى امتحانات به صورت مجازى بود و دانشجويان از هر مكانى امكان شركت در آزمون را داشتند و در بعضى موارد كنترل جلسه امتحان (از قبيل عدم تقلب، كمك ديكران و غيره) از عهده مسئولين مربوطه خارج بود. اين امر مىتوانست در نمرات آنها تأثير داشته باشد. لذا بايستى تحقيقاتى بعدى با ارزشيابىهاى حضورى دانشجويان در آينده انجام گردد. همجنين، فقط دانشجويان ورودى عوبا در دانشگاه علوم يزشكى رفسنجان از شيوه برنامهريزى فوق استفاده كرده و دوره را به اتمام رساندهاند، از ديخر محدوديتهاى مطالعه حاضر است. لذا تعميم نتايج بايستى با احتياط هر جه 
F

$$
\begin{aligned}
& \text { گَسترش يِيدا كند. امتياز متوسط ارزيابى كل حيطهها تجهيزات كلاسهاى آزمايشگاهى نيز براى ارائه بهتر و بهبود }
\end{aligned}
$$

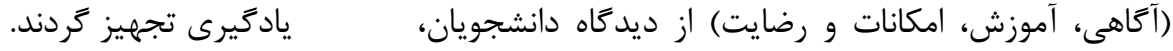

$$
\begin{aligned}
& \text { تحقيقات بيشترى را مىطلبد تا نقاط قوت و ضعف را به- }
\end{aligned}
$$

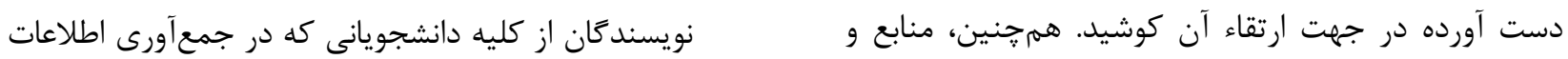

$$
\begin{aligned}
& \text { همكارى نموده، تشكر مىنمايند. }
\end{aligned}
$$

\section{References}

[1] Yamani N, Shater Jalali M. Curriculum integration, with Emphasis on Integration in Medical Education. Iran Jour of Med Edu 2012;

11(9): 1202-13. [Farsi]

[2] Pearson ML, Hubball HT. Curricular integration in pharmacy education. Am Jour of Pharmac Edu 2012; 76(10): 204.

[3] Harden RM. The Integration ladder: a tool for curriculum planning and evaluation. Med Edu Oxf 2000; 34(7): 551-7.

[4] Jaferi sani H, Karami M, Identifying the integration pattern of the humanities curriculum and its distance With the expected state of the students, according to Fogarty Quart Jour of Interdiscip Stud in the Hum 2013; 5(4): 119-34. [Farsi]

[5] Fogarty RJ. How to integrated curricula. America, Corwin Press; 2009, 22-116.

[6] Yazdani Sh, Hosseini F, Homayonizand R. General Medicine Curriculum Modifications Basic Science Phase Theoretical foundations and review of an experience Tehran: Mehrayaneh Publishing; 2007; 61-83. [Farsi]

[7] Nasiri asl M, Allami A. Survey of Qazvin medical students' attitudes toward the course integration 
program A. Jour Edu of Medi Sci 2010; 4: 90-6.

[Farsi]

[8] Raman VLM, Raju KS. Study on effectiveness of integrated lecture module versus didactic lecture module in learning skills. IOSR-JDMS 2015; 14(1): 14-6.

[9] Doraisamy R, Radhakrishnan S. The effectiveness of integrated teaching over traditional teaching among first year MBBS students: A preliminary study. Med JDY Patil Univ 2013; 6: 139-41.

[10] Ahmadipour H, Hajmohammadi F. Horizontal integration in basic sciences at Kerman University of Medical Sciences: medical students' viewpoint. Res Dev Med Educ 2016; 5(2): 93-6.

[11] Amini M, Kojouri J, Mahbudi A, Lotfi F, Seghatoleslam A, Karimian Z, et al. Implementation and evolution of the horizontal integration at shiraz medical school. Jour of $A d v$ in Med Edu \& Prof 2013; 1(1): 21-7.

[12] Zare-Khormizi MR, Dehghan M, Pourrajab F, Moghimi M, Farahmand-Rad R, Vakili-Zarch A. medical students Attitudes towards integration of pharmacology and pathology programs in Shahid sadoughi University of Medical Sciences. Research in Med Edu 2016; 8(1): 57-64.

[13] Kerman University of Medical Sciences, March 2020 http://sm.kmu.ac.ir/fa/page/34087.

1399.12.10

[14] Ministry of Culture and Higher Education GD, Program and Chapter of Medical Doctoral Courses, Medical Group 1104, http://sm.kmu.ac.ir/en/page/ 34087. 1399.12.10

[15] Allami A, Javadi A. Evaluation of medical student's pre-internship exam score in pathology before and after integration Program of physiopathology level in Qazvin. Resear in Med Edu 2013; 5(1): 31-5. [Farsi]

[16] Jalalian N, Rezaee M, Dehaghi AA. Survey of medical students' satisfaction with Kermanshah University of Medical Sciences from the integration program of physiopathology course. Horizon. Jour of Med Edu Develop 2011; 4: 93-9. [Farsi] 
عسז ا ارزيابى برنامه ادغام دروس ياتولوزى اختصاصى و فارماكولوزى

[17] Bahari A, Amin R, Ghobdar N. Integration of general medical physiopathology curriculum in Mashhad University of Medical Sciences. Ofoogh of Med Edu Develop 2011; 2(7): 29-32. [Farsi]

[18] Husain M, Khan S, Badyal D. Integration of medical education. Indian Pediatr 2020; 57(90): 842-7.

[19] Chhabra S, Mohammad S, Bahtia P, Ghatak S, Paliwal S, Soni P. Vertical integration in postgraduate teaching for anaesthesiology residents: A questionnaire based descriptive crosssectional study. Med J Armed Forces India 2021; 77: S220-S6.

[20] Valizageh M, Musavinasab N, Ahmadi A, Ali Rostam A. Comparison between Integrated Courses and discipline-based physiopathology Program in Zanjan University of Medical Science. Iran Jour of Med Edu 2013: 13(3); 201-11. [Farsi]

[21] Foroozan B, Anberi KH, Rezaeian J, Shirkhani S, Kholami M. The necessity of implementing the plan for horizontal integration of basic sciences and the satisfaction of professors and students from the implementation of the plan. Jour of
Lorestan Uni of Med Sci 2015; 17(3): 5-14. [Farsi]

[22] Walker D translate: Teimoori mh. curriculum theory is many things to many people, theory into practice (TIP).Curriculum theories, approaches and perspectives. Thehran: Samt and behnashr; 3 th ed with addictions, 2020; 137-46.

[23] Alimohammadi T, Rezaeian M, Bakhshi $\mathrm{H}$, Evaluation of medical school of Rafsanjan university of medical sciences on CIPP. Jour Raf of Med Sci. 2013; 12(3): 205-18. [Farsi]

[24] Rehman R, Iqbal A, Syed S. Evaluation of integrated learning program of undergraduate medical students. Pak J Physiol 2011; 7(2): 37-41.

[25] Sherer R, Wan Y, Dong H, Cooper B, Morgan I, Positive impact of integrating histology and physiology teaching at a medical school in China. Adv Physiol Educ 2014; 38: 330-8.

[26] Vashe A, Devi V, Rao R, Abraham RR, Pallath V, Umakanth, Sh. Using an integrated teaching approach to facilitate student achievement of the learning outcomes in a preclinical medical 
curriculum in India. Adv in Physiol Edu 2019;

43(4): 522-8.

[27] Eisenbarth S, Tilling T, Lueerss E, Meyer J, Sehner S, Guse AH, et al. Exploring the value and role of integrated supportive science courses in the reformed medical curriculum iMED: a mixed methods study. BMC Med Edu 2016; 16(1): 132.

[28] Miles S, Swift L, Leinster SJ. The Dundee ready education environment measure (DREEM) a review of its adoption and use. Med Teach 2012; 34(9): e620-e34.
[29] Alrasheedy AA. Multidisciplinary Integrated Pharmacotherapy Curriculum in a Doctor of Pharmacy Program: Educators' Perceptions, Views, and Perspectives. J Med Educ Curric Dev 2020; $7: 1-10$.

[30] Bandiera G, Bouncher A, Neville A, kuper A, Hodges B. Integration and timing of basic and clinical sciences education. Med Teach 2013; 35: $381-7$.

[31] Quintero GA, Vergel J, Arredondo M, Ariza MC, Gómez P, Pinzon-Barrios AM. Integrated medical curriculum: advantages and disadvantages. Jour of Med Edu and Curricul Develop 2016; 3: 133-7. 
^ץז ا ارزيابى برنامه ادغام دروس ياتولوزى اختصاصى و فارماكولوزى

\title{
Evaluation of the Integration of Specific Pathology and Pharmacology Courses from the Perspective of Medical Students and Academic Performance in Rafsanjan University of Medical Sciences in 2021: A Descriptive Study
}

\author{
V. Mirzaee ${ }^{1}$, R. Saberi ${ }^{2}$ E. Ehahrabadi ${ }^{3}$
}

Received: 26/04/21 Sent for Revision: 30/05/21 Received Revised Manuscript: 24/11/21 Accepted: 27/11/21

Background and Objectives: The effectiveness of the integration strategy in medical courses and academic performance is one of the most important issues. Therefore, the aim of this study was to evaluate the perspective of medical students to the program of integrating specific pathology and pharmacology courses and their academic performance in Rafsanjan University of Medical Sciences.

Materials and Methods: This descriptive study was performed in 2021. According to the census, all medical students of Rafsanjan University of Medical Sciences in 2017 (69 people) were studied in the physiopathology course. The data gathering tool was a five-point Likert scale. To measure performance, the GPA of physiopathology, and pathology, and pharmacology were examined. The analysis was performed using descriptive statistics (mean and standard deviation), independent t-test, and Pearson's and Spearman's correlation coefficient, and multiple linear regression.

Results: The highest score was related to satisfaction (3.72 \pm 0.65$)$. Teaching specific pathology (3.75 \pm 1.11$)$ and pharmacology (3.91 \pm 1.09$)$ by integration method had the highest scores. Repetition (2.20 \pm 0.99$)$, contrast of courses (2.88 \pm 0.99$)$, and overall evaluation (3.49 \pm 0.78$)$ had the average scores in the integration method. Predictor variables in predicting physiopathology GPA were specific pathology GPA $(B=0.825)$ and pharmacology $(B=0.152)$, respectively, and Pathology and Pharmacology GPA predicted $79.7 \%$ GPA of physiopathology course $(\mathrm{p}<0.001)$.

Conclusion: According to the average score of the students' views and their satisfaction with the presentation of specific pathology and pharmacology courses in the integration program and optimal performance, it is better to improve education and prevent inconsistency of the courses offered, efforts be made by course planners for better execution.

Key words: Integration strategy, Specific pathology, Pharmacology, Physiopathology course, Academic performance, Rafsanjan

Funding: This study was funded by Rafsanjan University of Medical Sciences.

Conflict of interest: None declared.

Ethical approval: The Ethics Committee of Rafsanjan University of Medical Sciences approved the study (IR.RUMS.REC.1400.005).

How to cite this article: Mirzaee V, Saberi R, Shahrabadi E. Evaluation of the Integration of Specific Pathology and Pharmacology Courses from the Perspective of Medical Students and Academic Performance in Rafsanjan University of Medical Sciences in 2021: A Descriptive Study. J Rafsanjan Univ Med Sci 2022; 20 (11): 1223-38. [Farsi]

\footnotetext{
1- Associate Prof. of Gastroenterol and Hepat Dept. of Internal Medicine, School of Medicine, Occupational Environmental Research Center, Rafsanjan University of Medical Sciences, Rafsanjan,Iran, ORCID: 0000-0003-0179-9224

2- Assistant Prof., Dept. of Education, Farhangian University, Tehran, Iran, ORCID: 0000-0002-6551-928X

3- MSc in Medical Education, Occupational Environmental Research Center, Rafsanjan University of Medical Sciences, Rafsanjan Iran, ORCID: 0000-0003-3965-4688

(Corresponding Author) Tel: (034) 31315016, Fax: (034) 31315003, E-mail: s_e_1400@yahoo.com
}

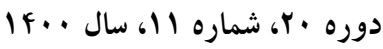

مجله دانشگاه علوم يزشكى رفسنجان 